\section{Nauplius}

The Journal of The

Brazilian Crustacean Society

e-ISSN 2358-2936

www.scielo.br/nau www.crustacea.org.br
This article is part of the special series

offered by the Brazilian Crustacean Society

in honor to Nilton José Hebling in recognition

of his dedication and contributions to the

development of carcinology in Brazil.

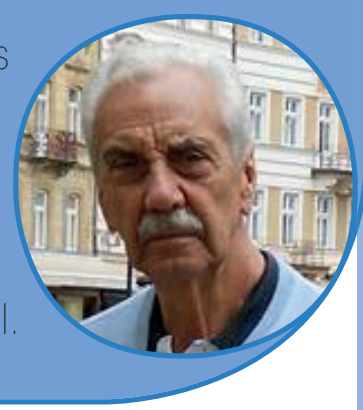

Original Article

\title{
Diversity and conservation status of Aegla spp. (Anomura, Aeglidae): an update
}

\author{
Sandro Santos ${ }^{1}$, Georgina Bond-Buckup ${ }^{2}$, Alberto Senra \\ Gonçalves $^{3}$, Marlise L. Bartholomei-Santos ${ }^{1}$, Ludwig Buckup ${ }^{2}$ \\ and Carlos G. Jara ${ }^{4}$
${ }^{1}$ Departamento de Ecologia e Evolução, Universidade Federal de Santa Maria. 97105- 900 Santa Maria, Rio Grande do Sul, Brazil.
2 Retired from Departamento de Zoologia, Instituto Biociências, Universidade Federal do Rio Grande do Sul, Av. Bento Gonçalves, 9500. 90501-970 Porto Alegre, Rio Grande do Sul, Brazil.

${ }^{3}$ Departamento Multidisciplinar, Unidade Descentralizada de Educação Superior da Universidade Federal de Santa Maria, Rua Francisco Guerino, 407. 97195-000 Silveira Martins, Rio Grande do Sul, Brazil.
${ }^{4}$ Instituto de Zoología, Universidad Austral de Chile, Campus Isla Teja, Casilla 567, Valdivia, Chile.

ZOOBANK http://zoobank.org/urn:lsid:zoobank.org:pub:A7252DAD-A10F-411094F0-890E2707F5EF

\begin{abstract}
The speciose genus Aegla Leach, 1820 is the only valid extant genus of the anomuran family Aeglidae, bearing 83 known species. This diversity may be even greater since there is some evidence for cryptic speciation. The genus is endemic to southern South America, occurring in freshwater habitats. We assessed the conservation status of 82 species of Aegla and found almost $70 \%$ of them under some level of threat, which represents a concerning proportion. Major threats to the group include freshwater pollution with urban, agricultural and industrial effluents, habitat modification and fragmentation, riparian forest removal, among others. Conservation measures are required to mitigate the major threats to freshwater ecosystems along rivers where the group occurs.
\end{abstract}

\section{KEY WORDS}

Anomuran crabs, Decapoda, freshwater crabs, South American creeks. 


\section{INTRODUCTION}

Taxonomically, the family Aeglidae was formerly included within the anomuran superfamily Galatheoidea, but morphological and molecular evidence (Martin and Abele, 1986; Tudge and Scheltinga, 2002; Pérez-Losada et al., 2002a; Ahyong and O'Meally, 2004) questioned this position. A reappraisal by McLaughlin et al. (2007) elevated Aeglidae to superfamily rank (Aegloidea).

Aegla Leach, 1820 is the only extant genus of the family Aeglidae and can be found in rivers, streams, and lakes of southern South America, occurring from the Rio Grande basin, on the border of São Paulo and Minas Gerais states, Brazil (Bueno et al., 2007), to Duque de York Island, South River basin, Chile (Oyanedel et al., 2011). This genus includes 83 described species (Bond-Buckup et al., 2008; 2010a; 2010b; Santos et al., 2012; 2013; 2015; Moraes et al., 2016) and probably new species will be uncovered in the next years (Fig. 1).

The use of molecular techniques together with traditional systematics has helped to confirm several new species, as the number of morphological characters for taxonomic use is limited by the conservative morphotype of the group (Bond-Buckup and Buckup, 1994; Pérez-Losada et al., 2004; Santos et al., 2009; $2010 ; 2012 ; 2013)$. Moreover, the existence of cryptic species cannot be ruled out since molecular markers and geometric morphometrics have already pointed to this possibility (Bartholomei-Santos et al., 2011; Marchiori et al., 2014; 2015). This level of diversity is greater than that observed for crayfishes of the family Parastacidae (Almerão et al., 2015) and brachyuran crabs of the genus Trichodactylus Latreille, 1828 (Yeo et al., 2006), other crustacean groups inhabiting southern South American continental waters. BondBuckup et al. (2008) estimated that $36.5 \%$ of the 63 species described at that time were under threat of extinction. Pérez-Losada et al. (2009) assessed the conservation status of 66 aeglid species and found that $32 \%$ of them were threatened, that is, species falling within the International Union for Nature Conservation (IUCN) categories Vulnerable (VU), Endangered (EN), and Critically Endangered (CR). Many factors contribute to threat the group along its distribution in southern South America, such as decline in habitat quality, water contamination by extensive

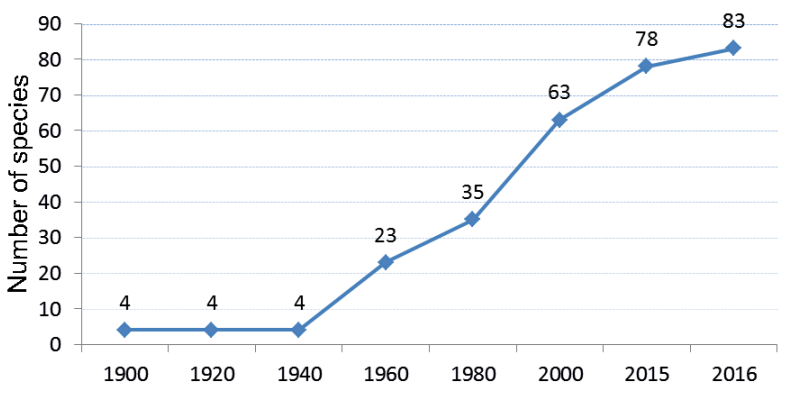

Figure 1. Cumulative number of known species of the genus Aegla Leach, 1820, since 1900.

use of pesticides in agriculture or by urban sewage, silvicultural practices, construction of hydroelectric plants, among others (Pérez-Losada et al., 2002b; Bond-Buckup et al., 2008; Baumart and Santos, 2010; Santos et al., 2012). The presence of some species in restrict areas, as in headwaters, several of them with a few records of occurrence, highlights even more the level of threat to the group's conservation (Magris et al., 2010).

In this study, we present data on the diversity of species of the genus Aegla, as well as updated information on the distribution of these species in different South American hydrographic basins. Moreover, based on data from several scientific collections and from years of work and experience of the authors, we evaluated the conservation status of the aeglid species and discussed the main threats to the genus diversity.

\section{Material and Methods}

We assessed and updated the distribution of 82 species of Aegla. Based on the updated distribution data, we revised the conservation status for each species previously assessed until 2016, according to the rules established by the International Union for Conservation of Nature (IUCN, 2012). There are five quantitative criteria $(\mathrm{A}-\mathrm{E})$ to be applied in order to evaluate if a taxon is under threat, and in which category the taxon should be included (EX - extinct; EW - extinct in wild; CR - critically endangered; EN - endangered; VU - vulnerable; NT - near threatened; LC - least concern; DD - deficient data; and NE - not evaluated; CR, EN and VU represent threat categories). The assessment employs sub-criteria to justify the assignment of a taxon to a certain category. Each species was evaluated in relation to its Extent Of Occurrence (EOO; sub-criterion B1) and Area Of Occupancy 
(AOO; sub-criterion B2), using data from literature (Bond-Buckup and Buckup, 1994; Jara and Palacios, 1999; Jara et al., 2003; Galves et al., 2007; Santos et al., 2009; 2010; 2012; 2013; 2014; 2015; Bond-Buckup et al., 2010a; 2010b; César and Damborenea, 2010; Oyanedel et al., 2011; Rocha and Bueno, 2011; Boos et al., 2012; Satterlee et al., 2012; Giri and Collins, 2014; Moraes et al., 2016) and from sampling records in scientific collections (Universidade Federal do Rio Grande do Sul, Universidade Federal de Santa Maria, Pontifícia Universidade Católica do Rio Grande do Sul, Fundação Zoobotânica do Rio Grande do Sul, Universidade Regional do Alto Uruguai e das Missões - Campus Erechim, Universidad Austral de Chile). We determined the $\mathrm{AOO}$ for species with less than four records, using an area measure unit (each pixel corresponds to an area of $1 \mathrm{~km}^{2}$ ). In this case, AOO ranged from 1 to $3 \mathrm{~km}^{2}$. For species with four or more records, we calculated the EOO. We assessed data for land-use classification for the whole occurrence area of Aeglidae from the Harmonized World Soil Database (http://webarchive.iiasa.ac.at/Research/ LUC/External-World-soil-database/HTML/), from the World Land Use - Land cover from Food and Agriculture Organization of the United Nations (FAO) (http://www.fao.org/geonetwork/srv/en/ metadata.show? $\mathrm{id}=12749$ \& currTab=simple), as well as from SOS Mata Atlântica and Instituto Nacional de Pesquisas Espaciais, 2011 (http://mapas.sosma. org.br).

\section{ResUlts}

The list of species, with author(s) and year of description, as well as their distributions, are presented in Tab. 1. Records indicate the presence of aeglids in rivers, lakes and streams in catchments in Argentina (14 species), Bolivia (1 species), Brazil (52 species), Chile (22 species, considering Aegla intermedia Girard, $1855)$, Paraguay (1 species) and Uruguay (4 species), some species occurring in more than one country (Figs. 2, 3).

Based on our assessment, 17 species were classified as critically endangered (CR), 21 as endangered (EN), 19 as vulnerable (VU), one as near threatened (NT), 21 as least concern (LC), three had deficient data (DD), and one was not evaluated (NE). Current and previous conservation status and the criteria used to assign each species to an IUCN category are also shown in Tab. 1.

\section{DiscusSION}

There are currently 83 known species of the genus Aegla, although the existence of $A$. intermedia is questioned. This species was described based upon specimens collected by the "U. S. N. Astronomical Expedition", in tributaries of Maipu River, near to Santiago, Chile. Despite the effort of various researchers, the species has never been found again in nature and its type-series has disappeared (BondBuckup and Buckup, 1994). Hence, the conservation status of this species was not evaluated.

Using updated data from the species distribution, we found 57 species of Aegla under threat or almost $70 \%$ of the 82 species evaluated. This proportion represents a significant increase in relation to previous assessments for the genus Aegla, which estimated nearly half of the present value (Bond-Buckup et al., 2008; Pérez-Losada et al., 2009). Considering the most recent conservation status assessment for each species, from the 32 species previously assessed as LC, only $20 \mathrm{kept}$ the same status; nine species changed the category to some level of threat and three have deficient data. Twenty-nine species kept the same threat category, but seven previously threatened species raised the threat level. Only one species changed from a threat category to NT status (Tab. 1).

Eighteen new species were described in the last decade (see Tab. 1). It is noteworthy that all the recently described species are under some level of threat (Santos et al., 2009; 2010; 2012; 2013; 2014; 2015; BondBuckup et al., 2010a; 2010b; Moraes et al., 2016). Two species previously considered extinct in the wild, Aegla expansa Jara, 1992 (Pérez-Losada et al., 2002a) and Aegla lata Bond-Buckup \& Buckup, 1994 (PérezLosada et al., 2009), have been found again (Galves et al., 2007; Ministerio del Medio Ambiente, Chile, 2013) and are currently categorized as endangered and critically endangered, respectively.

The high rate of endemism presented by many aeglid species, in association with habitat loss/fragmentation or even climatic events, has led many populations to decline (Maia et al., 2013; Bueno et al., 2014). Forty years ago, many species were found in several streams and rivers within a basin, but currently, most of them are restricted to low order creeks (Bond-Buckup and Buckup, 1994).

Threats to conservation of aeglids and other freshwater organisms in southern South America 


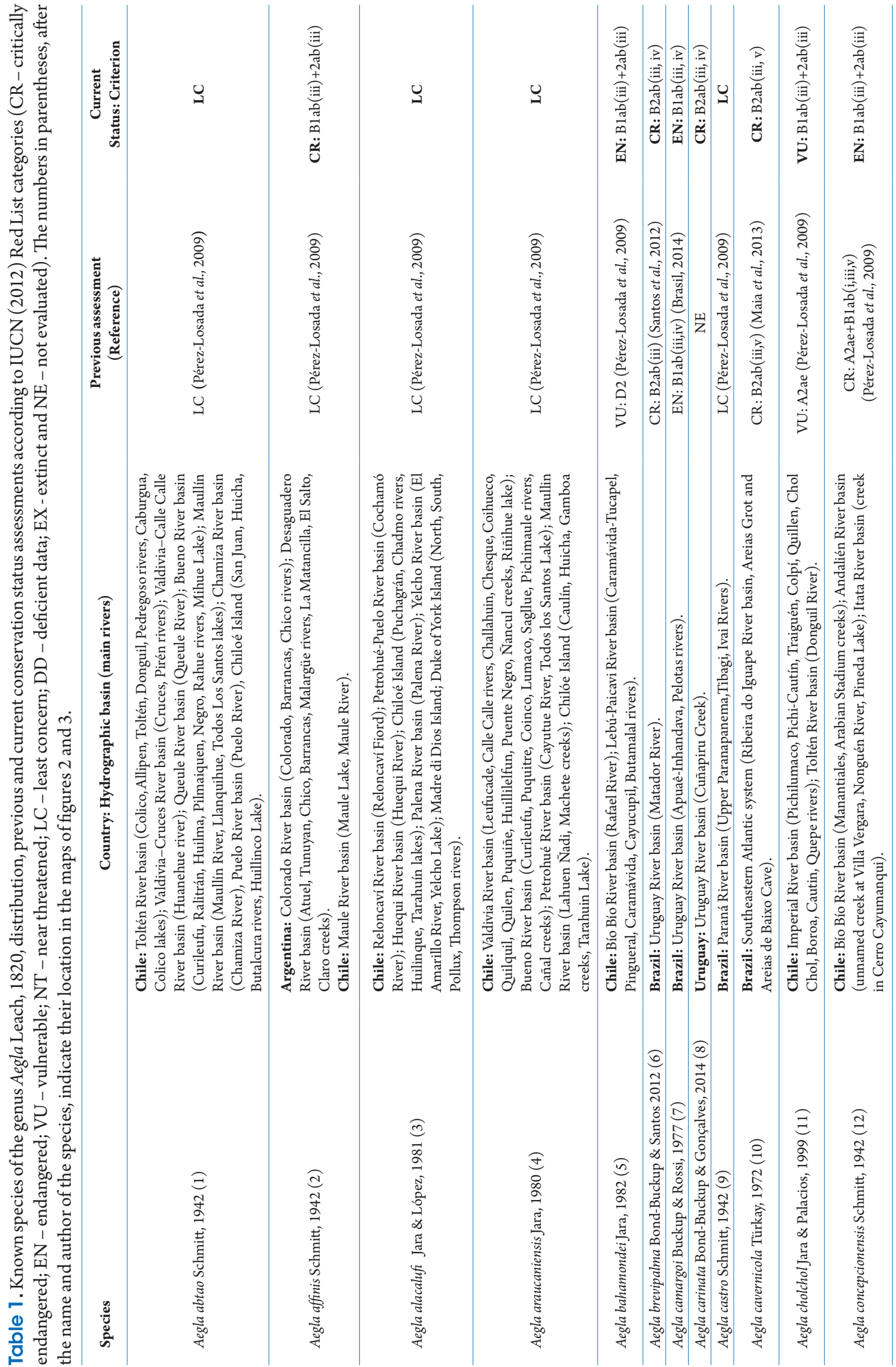



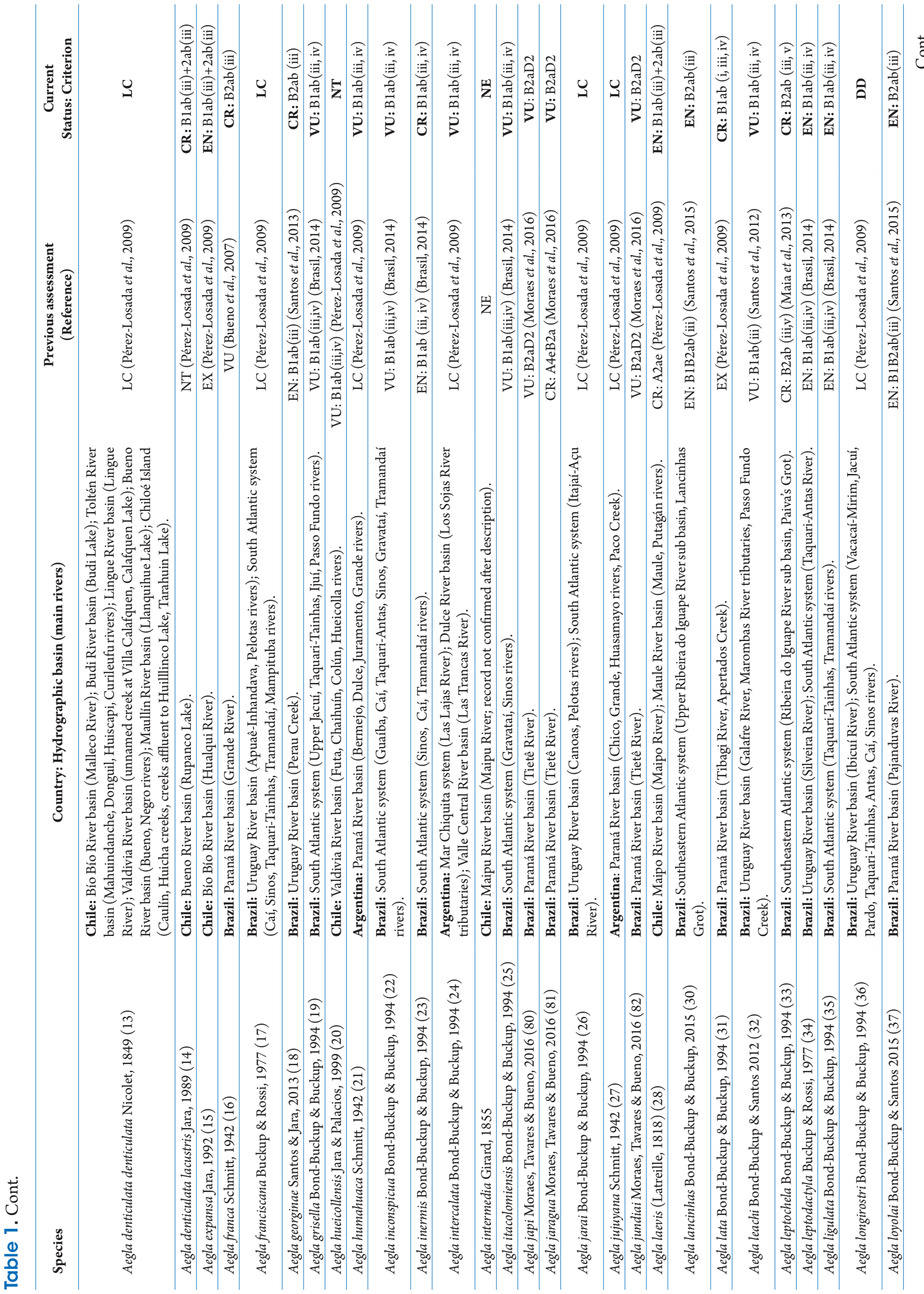


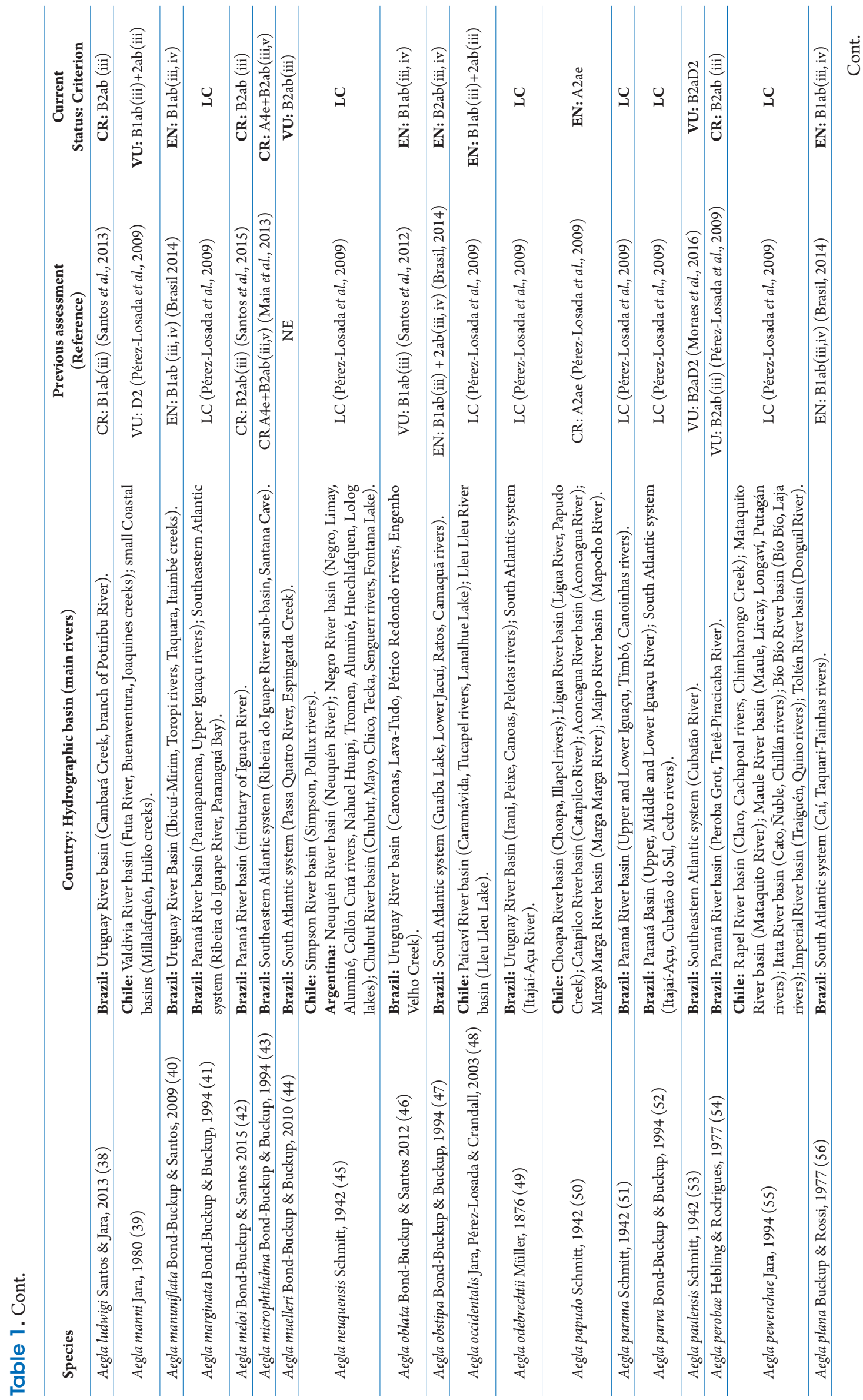




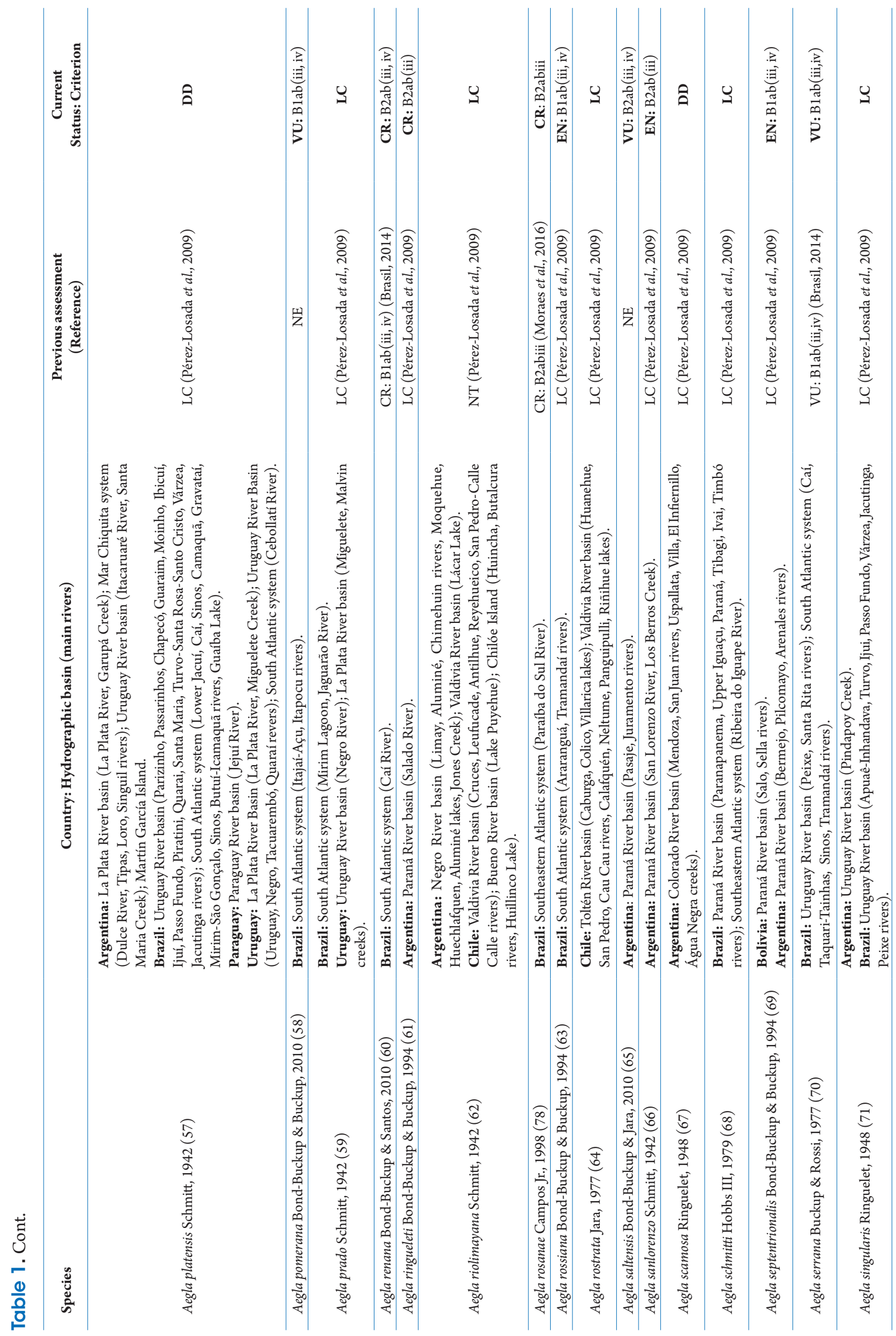




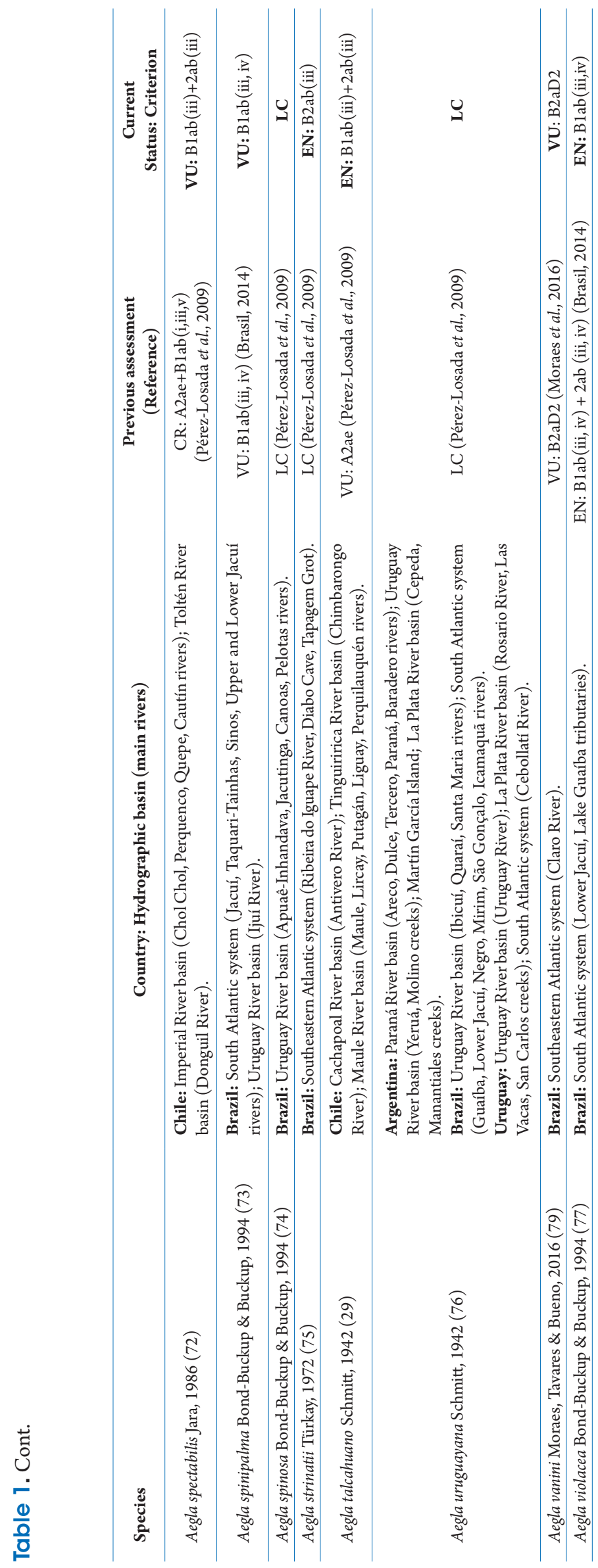




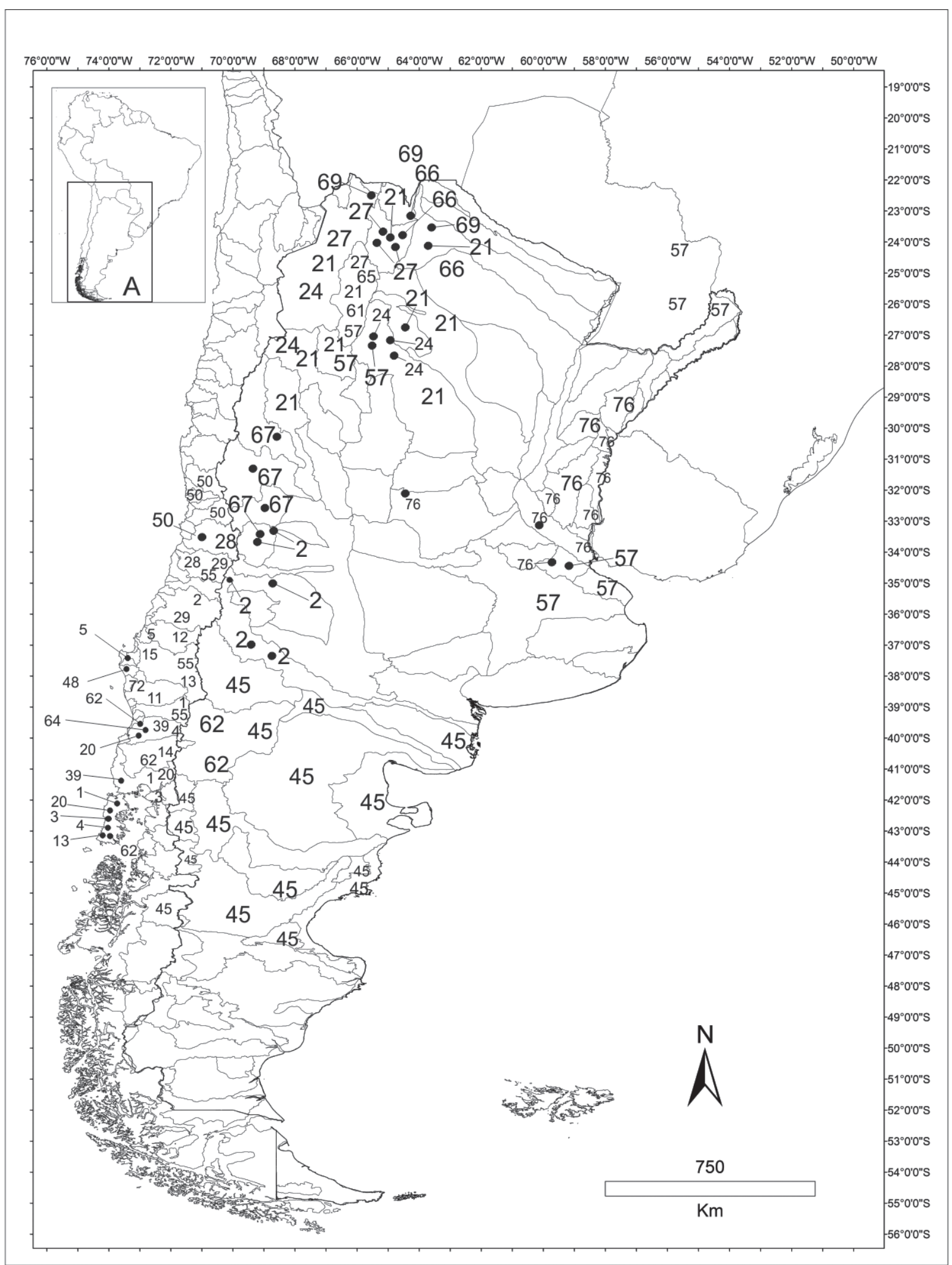

Figure 2. Distribution of Aegla Leach, 1820 in Argentina, Bolivia, Chile, and Paraguay (see Tab. 1 for the corresponding species number). In areas with less species diversity, we used a larger font size to facilitate the localization in the map. However, where diversity is high, to avoid overlapping the numbers, we reduced the font size, and if necessary we used a point with a line indicating the respective number. 


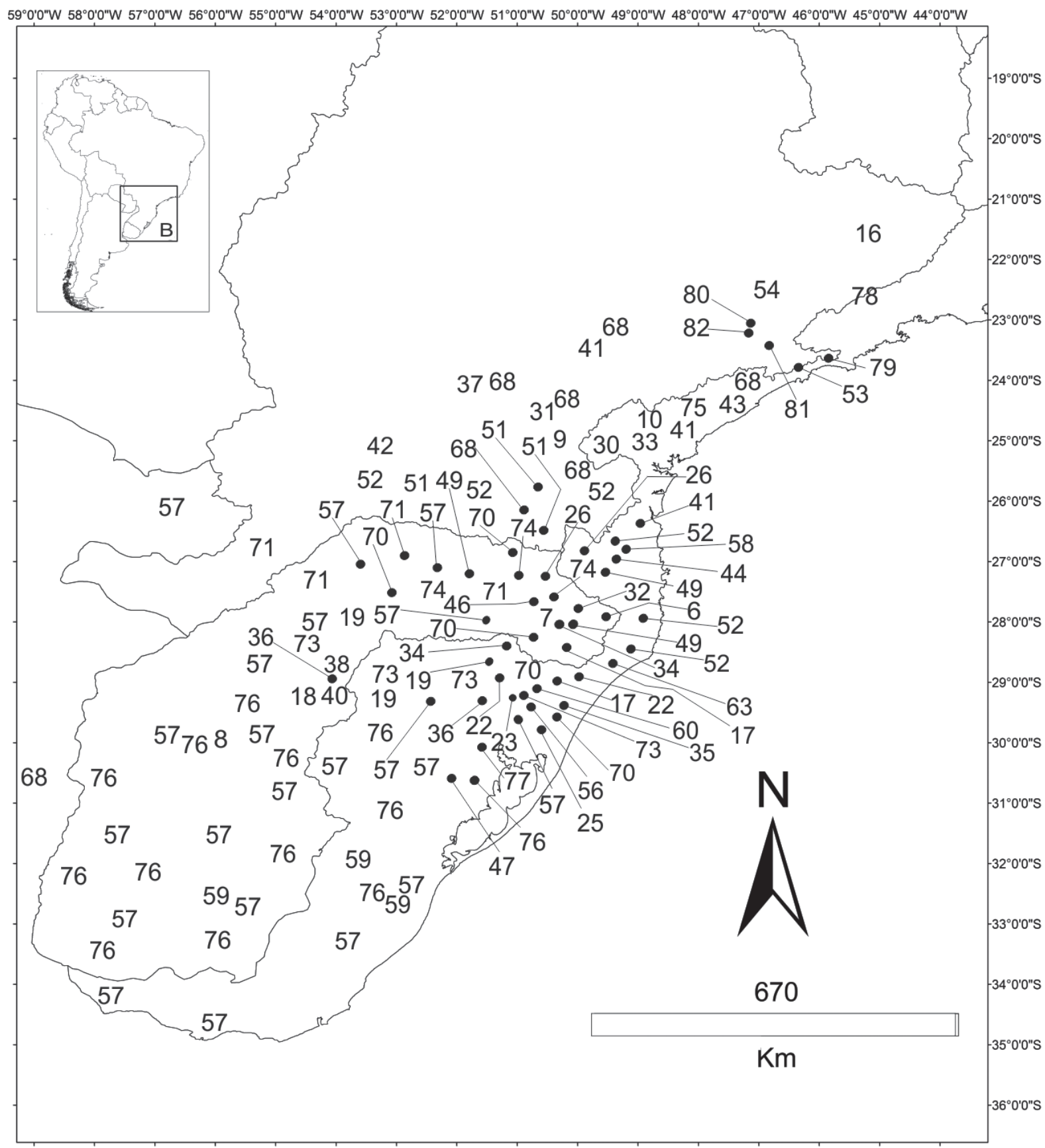

Figure 3. Distribution of Aegla Leach, 1820 in Brazil and Uruguay (see Tab. 1 for the corresponding species number). In areas with less species diversity, we used a larger font size to facilitate the localization in the map. However, where diversity is high, to avoid overlapping the numbers, we reduced the font size, and if necessary we used a point with a line indicating the respective number. 
derive from different sources: removal of riparian forest, causing siltation (Magris et al., 2010); habitat modification, fragmentation and destruction (Cumberlidge et al., 2009; Reid et al., 2013); freshwater contamination with agricultural pesticide (Magris et al., 2010; Negro et al., 2015; Stehle and Schulz, 2016); construction of dams that alter the flow and sometimes the temperature of the water as well (Olsson, 2015); urban and agricultural activities which modify the physical and chemical characteristics of water bodies and freshwater biota composition (Milesi et al., 2008; Hepp and Santos, 2009; Hepp et al., 2010; Magris et al., 2010); invasive species (Palaoro et al., 2013; Loureiro et al., 2015), among others.

Threats to the family Aeglidae, specifically, have been identified and listed, as the use of biocides in wine and fruit farms in Chile, silviculture of exotic species, largescale cultivation of potatoes and apples with extensive use of pesticides, and hog raising activities along southern rivers in Brazil (Bond-Buckup et al., 2008), beyond severe deforestation in Paraguay (Satterlee et al., 2012). Irrigated rice crops are responsible for the entrance of great amount of pesticides into the hydric systems (Bhuiyan and Castañeda, 1995), what may constitute a threat to aeglids in southern Brazil, Uruguay, Paraguay and northwestern Argentina. These activities, although doubtless important, negatively impact the aquatic environment, and it is imperative that they respect the principle of sustainability (Santos et al., 2012). In Argentina, the exotic golden mussel Limnoperna fortunae Dunker, 1857 was reported to settle on Aegla platensis Schmitt, 1942 affecting its populations (Darrigran and Damborenea, 2006). In Bolivia, anthropic activity and indiscriminate extraction by local people affect populations of Aegla septentrionalis Bond-Buckup \& Buckup, 1994 (Flores, 2010), the only aeglid species occurring in that country.

It should also be taken into account that many aeglid species present a narrow distribution, and two species with a relatively wide distribution, Aegla longirostri Bond-Buckup \& Buckup, 1994 and Aegla platensis, may represent a complex of cryptic species as supported by genetic and morphogeometric evidence (BartholomeiSantos et al., 2011; Marchiori et al., 2014; 2015). If this is true, so the distribution area of each cryptic species will be narrower than the "grouped" species, which can result in different conservation status for each cryptic species, the reason for which data were considered deficient for these two current recognized species.

Our assessment of the conservation status of all the currently known species of Aeglidae is worrisome, with $70 \%$ of the species under some level of threat and $20 \%$ critically endangered. Measures to protect the aeglid fauna are urgent, such as the frequent monitoring of water quality in systems where the threatened species occur, following-up the species to obtain information on possible population fluctuation or decline, protecting and restoring habitats, and information spreading among the population on the importance of water courses for conserving the native fauna, as well as encouraging agricultural practices that do not harm the water quality.

Aeglids live preferentially in clean waters (BondBuckup and Buckup, 1994), presenting a high demand for oxygen (Dalosto and Santos, 2011), and thus making these crustaceans potential good indicators of water quality. Policies for continental water quality control will help to protect not only the aeglids but also the limnetic fauna as a whole.

\section{ACKNOWLEDgeMENTS}

We are grateful to Dr. Nilton Hebling, the first author' s "scientific grandfather", for his wise teachings and wonderful legacy. We would like to thank $\mathrm{CNPq}$ for the productivity grant for SS (311142/2014-1).

\section{References}

Ahyong, S.A. and O'Meally, D. 2004. Phylogeny of the Decapoda Reptantia: resolution using three molecular loci and morphology. The Raffles Bulletin of Zoology, 52: 673-693.

Almerão, M.; Rudolph, E.; Souty-Grosset, C.; Crandall, K.A.; Buckup, L.; Amouret, J.; Verdi, A.; Santos, S. and Araújo, P.B. 2015. The native South American crayfishes (Crustacea, Parastacidae): state of knowledge and conservation status. Aquatic Conservation: Marine and Freshwater Ecosystems, 25: 288-301.

Bartholomei-Santos, M.L.; Roratto, P.A. and Santos, S. 2011. High genetic differentiation of Aegla longirostri (Crustacea, Decapoda, Anomura) populations in southern Brazil revealed by multi-loci microsatellite analysis. Genetics and Molecular Research, 10: 4133-4146.

Baumart, J.S. and Santos, S. 2010. The impact of herbicides on benthic organisms in flooded rice fields in southern Brazil. p. 369-382. In: A. Kortekamp (ed), Herbicides and Environmental. $1^{\text {st }}$ ed. Rijeka, Croatia, InTech. 
Bhuiyan, S.I. and Castañeda, A.R. 1995. The impact of ricefield pesticides on the quality of freshwater resources. p. 181-202. In: P.L. Pingali and P.A. Roger (eds) Impact of pesticides on farmer health and the rice environment. Norwell, Kluwer Academic Publishers.

Bond-Buckup, G. and Buckup, L. 1994. A família Aeglidae (Crustacea, Decapoda, Anomura). Arquivos de Zoologia, 32: 159-347.

Bond-Buckup, G.; Jara, C.G.; Buckup, L.; Bueno, A.P.; PerezLosada, M. and Crandall, K.A. 2010a. Description of a new species of Aeglidae, and new records of related species from river basins in Argentina (Crustacea, Anomura). Zootaxa, 2343: 18-30.

Bond-Buckup, G.; Jara, C.G.; Buckup, L.; Pérez-Losada, M.; Crandall, K.A. and Santos, S. 2010b. New species and new records of endemic freshwater crabs from the Atlantic forest in Southern Brazil (Anomura: Aeglidae). Journal of Crustacean Biology, 30: 495-502.

Bond-Buckup, G.; Jara, C.G.; Pérez-Losada, M.; Buckup, L. and Crandall, K.A. 2008. Global diversity of crabs (Aeglidae: Anomura: Decapoda) in freshwater. Hydrobiologia, 595: 267-273.

Boos, H.; Bond-Buckup, G.; Buckup, L.; Araujo, P.B.; Magalhães, C.; Almerão, M.P.; dos Santos, R.A. and Mantelatto, F.L. 2012. Checklist of the Crustacea from the state of Santa Catarina, Brazil. Check List, 8: 1020-1046.

Brasil. Decreto no. 51.797, de 08 de setembro de 2014. Declara as Espécies da Fauna Silvestre Ameaçadas de Extinção no Estado do Rio Grande do Sul. Anexo I. Táxons da fauna silvestre do Estado do Rio Grande do Sul ameaçados de extinção (categorias: Criticamente em Perigo -CR, Em Perigo -EN e Vulnerável -VU). Diário Oficial do Rio Grande do Sul, Porto Alegre, RS, 09 de setembro de 2014, no. 173, 2-12 (http:// corag.rs.gov.br/doe).

Bueno, S.L.S.; Shimizu, R.M. and Rocha, S.S. 2007. Estimating the population size of Aegla franca (Decapoda: Anomura: Aeglidae) by mark-recapture technique from an isolated section of Barro Preto stream, county of Claraval, state of Minas Gerais, southeastern Brazil. Journal of Crustacean Biology, 27: 553-559.

Bueno, S.L.S.; Takano, B.F.; Cohen, F.P.A.; Moraes, J.C.B.; Chiquetto-Machado, P.I.; Vieira, L.C.M. and Shimizu, R.M. 2014. Fluctuations in the population size of the highly endemic Aegla perobae (Decapoda: Anomura: Aeglidae) caused by a disturbance event. Journal of Crustacean Biology, 34: 165-173.

César, I.I. and Damborenea, C. 2010. Type and non-type specimens of Aegla (Decapoda: Anomura: Aeglidae) housed in the Museo de La Plata, Argentina. Zootaxa, 2337: 31-46.

Cumberlidge, N.; Ng, P.K.L.; Yeo, D.C.J.; Magalhães, C; Campos, M.R.; Alvarez, F.; Naruse, T.; Daniels, S.R.; Esser, L.J.; Attipoe, F.Y.K.; Clotilde-Ba, F.-L.; Darwall, W.; McIvor, A.; Baillie, J.E.M.; Collen, B. and Ram, M. 2009. Freshwater crabs and the biodiversity crisis: Importance, threats, status, and conservation challenges. Biological Conservation, 142: 1665-1673.
Dalosto, M. and Santos, S. 2011. Differences in oxygen consumption and diel activity as adaptations related to microhabitat in Neotropical freshwater decapods (Crustacea). Comparative Biochemistry and Physiology, Part A, 160: 461-466.

Darrigran, G. and Damborenea, C. 2006. Características de la especie.p. 53-70. In: G. Darrigran and C. Damborenea (Eds) Bio-invasión del mejillón dorado en el continente Americano. La Plata, Univ. Nacional de La Plata.

Flores, V.G.B. 2010. Identificación de factores que afectan la estructura poblacional del cangrejo de río (Aegla septentrionalis) en dos vertientes del Municipio de Tupiza (Dpto. Potosí). Facultad de Agronomia, Universidad Mayor de San Andrés, La Paz, Bolívia, Graduation thesis. 104p. [Unpublished].

Galves, W.; Jerep, F.C. and Shibatta, O.A. 2007. Estudo da condição ambiental pelo levantamento da fauna de três riachos da região do Parque Estadual Mata dos Godoy (PEMG), Londrina, PR, Brasil. Pan-American Journal of Aquatic Sciences, 2: 55-65.

Giri, F. and Collins, P. 2014. Clinal variation in carapace shape in the South American freshwater crab, Aegla uruguayana (Anomura: Aeglidae). Biological Journal of the Linnean Society, 113: 914-930.

Hepp, L.U.; Milesi, S.V.; Biasi, C. and Restello, R.M. 2010. Effects of agricultural and urban impacts on macroinvertebrates assemblages in streams (Rio Grande do Sul, Brazil). Zoologia, 27: 106-113.

Hepp, L.U. and Santos, S. 2009. Benthic communities of streams related to different land uses in a hydrographic basin in southern Brazil. Environmental Monitoring and Assessment, 157: 305-318.

IUCN (International Union for Conservation of Nature). 2012. IUCN Red List Categories and Criteria: Version 3.1. Second edition. IUCN, Gland, Switzerland and Cambridge, UK.

Jara, C. and Palacios, V.L. 1999. Two new species of Aegla Leach (Crustacea: Anomura: Aeglidae). Proceedings of the Biological Society of Washington, 112: 106-109.

Jara, C.G.; Pérez-Losada, M. and Crandall, K.A. 2003. A new species of freshwater anomuran crab of the genus Aegla (Crustacea: Decapoda: Aeglidae) from the Nahuelbuta Coastal Range, Chile. Proceedings of the Biological Society of Washington, 116: 933-942.

Loureiro, T.G.; Anastácio, P.M.; Bueno, S.L.S.; Araujo, P.B.; Souty-Grosset, C. and Almerão, M.P. 2015. Distribution, introduction pathway, and invasion risk analysis of the North American crayfish Procambarus clarkii (Decapoda: Cambaridae) in Southeast Brazil. Journal of Crustacean Biology, 35(1): 88-96.

Magris, R.A.; Bond-Buckup, G.; Magalhães, C.; Mantelatto, F.L; Reid, J.W.; Loureiro, L.M.A.E.; Coelho, P.A.; Santana, W.; Buckup, L.; Rocha, S.S.; Bueno, S.L.S.; Pinheiro, M.A.A.; D’Incao, F.; Ivo, C.T.C.; Dias Neto, J.; Rodrigues, E.S.; Araujo, P.B.; Boos Jr, H. and Duarte L.F.A. 2010. Quantification of extinction risk for crustacean species: an overview of the National Red Listing process in Brazil. Nauplius, 18: 129-135. 
Maia, K.P.; Bueno, S.L.S. and Trajano, E. 2013. Ecologia populacional e conservação de eglídeos (Crustacea: Decapoda: Aeglidae) em cavernas da área cárstica do Alto Ribeira, em São Paulo. Revista da Biologia, 10: 40-45.

Marchiori, A.B.; Bartholomei-Santos, M.L. and Santos, S. 2014. Intraspecific variation in Aegla longirostri (Crustacea: Decapoda: Anomura) revealed by geometric morphometrics: evidence for ongoing speciation? Biological Journal of the Linnean Society, 112: 31-39.

Marchiori, A.B.; Fornel, R. and Santos, S. 2015. Morphometric variation in allopatric populations of Aegla platensis (Crustacea: Decapoda: Anomura): possible evidence for cryptic speciation. Zoomorphology, 134: 45-53.

Martin, J.W. and Abele, L.G. 1986. Phylogenetic relationships of the genus Aegla (Decapoda, Anomura, Aeglidae), with comments on anomuran phylogeny. Journal of Crustacean Biology, 6: 576-616.

McLaughlin, P.A.; Lemaitre, R. and Sorhannus, U. 2007. Hermit crab phylogeny: a reappraisal and its "fall-out". Journal of Crustacean Biology, 27: 97-115.

Milesi, S.V.; Biasi, C.; Restello, R.M. and Hepp, L.U. 2008. Efeito de metais Cobre $(\mathrm{Cu})$ e Zinco $(\mathrm{Zn})$ sobre a comunidade de macroinvertebrados bentônicos em riachos do sul do Brasil. Acta Scientiarum - Biological Sciences, 30: 283-289.

Ministerio del Medio Ambiente, Chile. 2013. Available at http:/ / www.mma.gob.cl/clasificacionespecies/fichas 10proceso/ fichas_10_pac/Aegla_expansa_10RCE_04_PAC.pdf

Moraes, J.C.; Terossi, M.; Buranelli, R.C.; Tavares, M.; Mantelatto, F.L. and Bueno, S.L.S. 2016. Morphological and molecular data reveal the cryptic diversity among populations of Aegla paulensis (Decapoda, Anomura, Aeglidae), with descriptions of four new species and comments on dispersal routes and conservation status. Zootaxa, 4193: 1-48.

Negro, C.L.; Senkman, L.E.; Marino, F.; Lorenzatti, E. and Collins, P. 2015. Pesticide effects on crabs: how environmental concentrations of endosulfan and chlorpyrifos affect embryos. Journal of Environmental Science and Health, Part B, 50: 261265.

Olsson, G. 2015. Water and energy: threats and opportunities. Second Edition. London, IWA Publishing, 496p.

Oyanedel, A.; Valdovinos, C.; Sandoval, N.; Moya, C.; Kiessling, G.; Salvo, J. and Olmos, V. 2011. The Southernmost freshwater anomurans of the world: geographic distribution and new records of Patagonian aeglids (Decapoda: Aeglidae). Journal of Crustacean Biology, 31: 396-400.

Palaoro, A.V.; Dalosto, M.M.; Costa, G.C. and Santos, S. 2013. Niche conservatism and the potential for the crayfish Procambarus clarkii to invade South America. Freshwater Biology, 58: 1379-1391.

Pérez-Losada, M., Bond-Buckup, G.; Jara, C.G. and Crandall, K.A. 2004. Molecular systematics and biogeography of the southern South American freshwater "crabs" Aegla (Decapoda, Anomura, Aeglidae) using multiple heuristic tree search approaches. Systematic Biology, 53: 767-780.
Pérez-Losada, M., Bond-Buckup, G.; Jara, C.G. and Crandall, K.A. 2009. Conservation assessment of southern South American freshwater ecoregions on the basis of the distribution and genetic diversity of crabs from the genus Aegla. Conservation Biology, 23: 692-702.

Pérez-Losada, M., Jara, C.G.; Bond-Buckup, G.; and Crandall. K.A. 2002b. Conservation phylogenetics of Chilean freshwater crabs Aegla (Anomura, Aeglidae): assigning priorities for aquatic habitat protection. Biological Conservation, 105: 345-353.

Pérez-Losada, M., Jara, C.G.; Bond-Buckup, G.; Porter, M.L. and Crandall. K.A. 2002a. Anomuran phylogenetic relationships: on the taxonomic positioning of Aeglidae freshwater crabs. Journal of Crustacean Biology, 22: 670-676.

Reid, G. McG., Contreras McBeath, T. and Csatádi, K. 2013. Global challenges in freshwater fish conservation related to public aquariums and the aquarium industry. International Zoo Yearbook, 47: 6-45.

Rocha, S.S. and Bueno, S.L.S. Extension of the known distribution of Aegla strinatii Türkay, 1972 and a checklist of decapod crustaceans (Aeglidae, Palaemonidae and Trichodactylidae) from the Jacupiranga State Park, South of São Paulo State, Brazil. 2011. Nauplius, 19: 163-167.

Santos, S.; Bond-Buckup, G.; Buckup, L.; Bartholomei-Santos, M.L.; Pérez-Losada, M.; Jara, C.G. and Crandall, K.A. 2015. Three new species of Aeglidae (Aegla Leach, 1820) from Paraná State, Brazil. Journal of Crustacean Biology, 35: 839-849.

Santos, S.; Bond-Buckup, G.; Buckup, L.; Loureiro, T.G.; Gonçalves, A.S.; Verdi, A.; Scarabino F. and Clavijo, C. 2014. The Aeglidae of Uruguay (Decapoda, Anomura), with the description of a new species of Aegla. Crustaceana Monographs, 19: 195-205.

Santos, S.; Bond-Buckup, G.; Buckup, L.; Pérez-Losada, M.; Finley, M. and Crandall, K.A. 2012. Three new species of Aegla (Anomura) freshwater crabs from the Upper Uruguay River hydrographic basin in Brazil. Journal of Crustacean Biology, 32: 529-540.

Santos, S.; Bond-Buckup, G.; Pérez-Losada, M.; BartholomeiSantos, M.L. and Buckup, L. 2009. Aegla manuinflata, a new species of freshwater anomuran (Decapoda: Anomura: Aeglidae). Zootaxa, 2088: 31-40.

Santos, S.; Bond-Buckup, G.; Pérez-Losada, M.; Jara, C.G.; Crandall, K.A. and Buckup, L. 2010. New records and description of a new species of Aeglidae (Crustacea: Anomura) from river basins in Southern Brazil. Nauplius, 18: 79-86.

Santos, S.; Jara, C.G.; Bartholomei-Santos, M.L.; Pérez-Losada, M. and Crandall, K.A. 2013. New species and records of the genus Aegla Leach, 1820 (Crustacea, Anomura, Aeglidae) from the West-Central region of Rio Grande do Sul, Brazil. Nauplius, 21: 211-223.

Satterlee, S.A.; Zuercher, G.L.; Kuhle, C.W.; Ramírez-Pinto, F.; Fernández, S.; Jackson, L.; Velázquez, M.C. and Kochalka, J.A. 2012. Rediscovery of aeglid crabs in the Rio Jejuí watershed, Paraguay. Journal of Crustacean Biology, 32: 541-543. 
Stehle, S. and Schulz, R. 2016. Agricultural insecticides threaten surface waters at the global scale. Proceedings of the National Academy of Sciences, USA, 112: 5750-5755.

Tudge, C.C. and Scheltinga, D.M. 2002. Spermatozoal morphology of the freshwater anomuran Aegla longirostris Bond-Buckup and Buckup, 1994 (Crustacea: Decapoda: Aeglidae) from
South America. Proceedings of the Biological Society of Washington, 115: 118-128.

Yeo, D.C.; Ng, J.P.K.L.; Cumberlidge, N.; Magalhães, C.; Daniels, S.R. and Campos, M.R. 2006. A global assessment of freshwater crab diversity (Crustacea: Decapoda: Brachyura). Hydrobiologia, 595: 275-286. 